\title{
Model Space Time Autoregressive (STAR) dan Aplikasinya Terhadap Penyakit Demam Berdarah Dengue di Provinsi Sulawesi Barat
}

\author{
Wahidah Sanusi ${ }^{1}$, Maya Sari Wahyuni ${ }^{1}$, dan Rahmat Setiawan ${ }^{1, \text { a) }}$ \\ ${ }^{1}$ Jurusan Matematika, Fakultas Matematika dan Ilmu Pengetahuan Alam, Universitas Negeri \\ Makassar \\ a)setiawan_rahmat19@yahoo.com
}

\begin{abstract}
Abstrak. Model Space Time Autoregressive (STAR) merupakan data deret waktu yang mempunyai keterkaitan antar lokasi (space time). Tujuan dari penelitian ini adalah untuk mendapatkan model STAR yang sesuai dengan data jumlah penderita penyakit DBD di Provinsi Sulawesi Barat serta memperoleh data hasil ramalan untuk beberapa bulan kedepan. Data yang digunakan merupakan data bulanan penderita DBD di lima lokasi yaitu Kota Mamuju, Kabupaten Majene, Kabupaten Polmas, Kabupaten Mamuju Tengah, dan Kabupaten Maтuju Utara pada Januari 2014 sampai Juli 2016. Pendugaan parameter model STAR menggunakan metode kuadrat terkecil (MKT). Model STAR yang sesuai dengan data jumlah penderita penyakit DBD di Provinsi Sulawesi Barat adalah model STAR ${ }_{5}\left(1_{1}\right)$. Pembobot yang digunakan merupakan bobot lokasi seragam. Pada hasil pengecekan parameter penduga dengan menggunakan bobot lokasi seragam didapatkan tiga model. Hal ini dilihat dari adanya pengaruh yang nyata terhadap lokasi yang berdekatan. Hasil ramalan dengan model STAR $S_{5}\left(1_{1}\right)$ tentang jumlah penderita penyakit DBD di Provinsi Sulawesi Barat untuk dua bulan kedepan yaitu bulan Agustus sampai September 2016.
\end{abstract}

Kata Kunci: Model STAR, ARIMA, Autoregressive, Deret Waktu

\begin{abstract}
The Space Time Autoregressive (STAR) model is a time series data that has a link between locations (space time). The purpose of this study was to obtain a STAR model that was in accordance with the data on the number of dengue fever patients in West Sulawesi Province and also the forecast data for the next few months. Data in the form of DHF data in five locations, namely Mamuju City, Majene Regency, Polmas District, Central Mamuju Regency, and North Mamuju Regency from January 2014 to July 2016. STAR Estimation parameter model uses vertical squares (MKT) method. The STAR model that matches the data on the number of DHF patients in West Sulawesi Province is the STAR model $\left._{(1}\right)$. The weighting is a uniform location. In the estimator checking results using uniform location weight of three models. Things that happen between others. Forecast results with the STAR ${ }_{5}\left(1_{1}\right)$ model on the number of dengue fever patients in West Sulawesi Province for the next two months, namely August to September 2016, namely 9 people for Maтuju City and 12 people for Polman Regency.
\end{abstract}

Keywords: STAR Model, ARIMA, Autoregressive, Time Series

\section{PENDAHULUAN}

Model Space Time (ruang waktu) salah satu model yang menggabungkan unsur dependensi waktu dan lokasi pada data deret waktu multivariate (Rahman, 2013). Salah satu model yang menggunakan unsur dependensi waktu dan lokasi yaitu model Space Time Autoregressive (STAR). Model STAR merupakan gabungan model autoregressive orde $\mathrm{p}\left(\mathrm{AR}_{\mathrm{p}}\right)$ dari model Box-Jenkins dan model spasial (Ilham, 2017). 
Beberapa penelitian yang telah dilakukan terkait dengan model STAR (Suhartini, 2007; Retnaningrum, 2015; Suhartono, 2007; Suryamah, 2013; Purnomo, 2015). Suhartini (2007)membahas tentang peramalan dengan model ARCH. Penelitian ini menyimpulkan bahwa peramalan dengan menggunakan model $\mathrm{ARCH}$ tidak dapat mendeteksi faktor-faktor yang mempengaruhi perubahan harga yang signifikan. Selain itu, Retnaningrum (2015) menerapkanmodel STAR dan ARIMA untuk peramalan data curah hujan di Kabupaten Jember. Dalam penelitian ini menjelaskan bahwa peramalan dengan menggunakan model STAR memiliki ketepatan yang lebih baik dibandingkan model ARIMA.Pada penelitian ini mengkaji model STAR terkait masalah Demam Berdarah Dengue (DBD) di Provinsi Sulawesi Barat.

Demam berdarah Dengue (DBD) masih merupakan salah satu masalah kesehatan masyarakat yang utama di Indonesia. Seiring dengan meningkatnya mobilitas dan kepadatan penduduk, jumlah penderita dan luas daerah penyebarannya semakin bertambah. Di Indonesia, demam berdarah pertama kali ditemukan di kota Surabaya pada tahun 1968, dimana sebanyak 58 orang terinfeksi dan 24 orang diantaranya meninggal dunia, dengan Angka Kematian (AK) mencapai $41,3 \%$. Sejak saat itu, penyakit ini menyebar luas ke seluruh Indonesia (Kementerian Kesehatan, 2010).

Penelitian ini diharapkan memperoleh model peramalan untuk mengantisipasi jumlah penderita penyakit DBD diProvinsi Sulawesi Barat. Hasil ramalan tersebut dapat digunakan sebagai perencanaan dalam menanggulangi penyakit DBD.

\section{KAJIAN PUSTAKA}

\section{Model STAR}

Autoregressive (AR) adalah model dimana pelaku variabel dependen dipengaruhi oleh nilai variabel tersebut pada satu atau beberapa periode sebelumnya. Hal ini dapat dilihat pada persamaan (1).

$$
y(t)=\phi_{0}+\phi_{1} y(t-1)+\phi_{2} y(t-2)+\cdots+\phi_{p} y(t-p)+e(t)
$$

Dengan,

$$
\begin{array}{ll}
y(t) & \text { : Besarnya pengamatan (kejadian) pada waktu ke-t } \\
e(t) & \text { : Nilai galat } \text { error pada waktu ke-t } \\
\phi_{p} & \text { : Parameter autoregressive pada lag waktu ke-p }
\end{array}
$$

Model yang dapat menjelaskan hubungan antara suatu lokasi dan sekitarnya adalah model spasial. Permasalahan yang sering muncul dalam model spasial adalah pemilihan atau penentuan bobot lokasi seragam. Model Space Time Autoregressive (STAR) adalah model yang dikategorikan berdasarkan lag yang berpengaruh secara linear baik dalam lokasi maupun waktu (pfeifer and Deutsch 1980), persamaan model STAR ( $p, \lambda k)$ seperti pada persamaan (2).

$$
y(t)=\sum_{l=0}^{\lambda k} \sum_{k=1}^{p} \Phi_{k l} W^{l} y(t-k)+e(t)
$$

Dengan,

$p \quad$ : Lag waktu

$\lambda k \quad$ : Lag spasial

$\Phi_{k l} \quad$ : Parameter STAR pada lag waktu $k$ dan lag spasial $l$

$W^{l} \quad$ : Matriks bobot ukuran $(n \times n)$ pada lag spasial $l$ dengan $W^{0}$ adalah mariks identitas ukuran $(n \times n)$

$e(t) \quad$ : Vektor sisaan berukuran ( $n x \quad 1)$ pada waktu ke- $t$

$y(t) \quad$ : Vektor data deret waktu ukuran $(n x 1)$ pada waktu ke- $t$ 


\section{Stasioneritas}

Kestasioneran merupakan syaratutama dalam analisis deret waktu. Uji untuk melihat kestasioneran data dengan membuat plot antara nilai observasi dan waktu. Kemudian, jika diperkirakan nilai tengah dan ragam konstan pada plot tersebutmaka data tersebut stasioner. Jika data tidak stasioner dalam rataan (mean) maka perlu dilakukan diffrencing sedangkan jika data tidak ragam konstan (varian) maka perlu dilakukan transformasi Box-Cox.Kestasioneran juga dapat dilihat dengan menggunakan uji Augmented Dickey-Fuller (ADF) untuk memeriksa kestasioneran terhadapat rataan (mean) maupun ragam konstan (varian) untuk. Hipotesis yang digunakan pada uji ADF (Daraputri, 2015; Sedighi, 2000) adalah:

$\mathrm{H}_{0}=$ terdapat akar uhnit, data tidak stasioner

$\mathrm{H}_{1}=$ tidak terdapat akar unit, data tidak stasioner

Kriteria keputusan adalah bahwa $\mathrm{H}_{0}$ ditolak apabila nilai statistik dari uji ADF lebih besar dari pada nilai kritis MacKinnon sehingga disimpulkan data stasioner. Secara umum, formulasi data uji ADF dapat dilihat pada persamaan (3).

$$
\Delta y(t)=\alpha_{0}+\alpha_{1} t+\gamma y(t-1)+\sum_{i=2}^{p} \gamma y(t-i+1)+e(t)
$$

Dengan,

$\Delta y(t)$ : Selisih data pengamatannya waktu ke- $t$ dengan waktu sebelumnya

$y(t) \quad$ : Nilai deret waktu ke- $t$

$\alpha_{0}, \alpha_{1}:$ Konstanta

$\gamma \quad$ : Keofisien dari autoregressive

$e(t) \quad$ : Nilai sisaan pada waktu ke- $t$

\section{Estimasi Parameter}

Dalam melakukan estimasi parameter model STAR ditentukan dengan menggunakan Metode Kuadrat Terkecil (MKT).MKT diperoleh dengan menentukan nilai $\hat{\phi}_{k l}$ yang menghasilkan jumlah kuadrat residu minimum. Apabila diambil sebuah model STAR $\left(1_{1}\right)$ seperti persamaan (4)(Retnaningrum,2015; Ruchjana, 2001).

$$
Z(t)=\phi_{10} Z(t-1)+\phi_{11} W Z(t-1)+e(t)
$$

\section{Pembobotan Model STAR}

Untuk pemilihan atau penetuan bobot lokasi pada model STAR, dilakukan dengan menggunakan matriks bobot seragam. Matriks bobot merupakan matriks bujur sangkar yang memiliki entri-entri berupa bobot lokasi yang bersesuaian. Bobot untuk entri matriks pada model STAR biasanya ditentukan dengan memperhatikan sifat-sifat atau karakteristik misalnya luas wilayah, kepadatan penduduk, batas antara dua lokasi, atau sarana transformasi, dimana setiap bobot tersebut tidak tergantung pada waktu.

Bobot $W_{i j}$ pada lag spasial 1 dinyatakan oleh $\mathrm{W}$ berupa matriks bujur sangkar $N X N$ sebagai berikut:

$$
W=\left[\begin{array}{cccc}
0 & W_{12} & \ldots & W_{1 N} \\
W_{21} & 0 & \ldots & W_{2 N} \\
\vdots & \vdots & & \ddots \\
W_{N 1} & W_{N 2} & \ldots & 0
\end{array}\right]
$$

Salah satu bobot yang sering digunakan adalah bobot seragam. Bobot seragam ditentukan berdasarkan banyaknya tetangga terdekat dalam suatu kelompok lokasi tertentu (lag spasial). Secara matematis bobot seragam ditentukan sebagai berikut: 


$$
W_{i j}=\left\{\begin{array}{cc}
\frac{1}{N}, & \text { jika i dan j merupakan tetangga terdekat } \\
0, & \text { jika lainnya. }
\end{array}\right.
$$

Dengan sifat $\mathrm{N}$ menyatakan banyaknya tetangga terdekat dari lokasi $i$ pada lag spasial 1 . Sifatsifat matriks bobot seragam diantaranya:

$$
\begin{gathered}
W_{i j}>0 \\
\sum_{j=1}^{N} W_{i j}=1 \text { untuk setiap } i \text { dan } \sum_{i=1}^{N} \sum_{j=1}^{N} W_{i j}=N \\
\text { Diagonal matriks bobot W adalah nol (Retnaningrum dalam Ruchjana, 2001). }
\end{gathered}
$$

\section{METODE PENELITIAN}

Penelitian ini merupakan penelitian terapan yang bertujuan mengetahui hasil ramalan data penderita penyakit DBD di provinsi Sulawesi Barat. Berdasarkan data yang diperoleh dari Dinas Kesehatan Prvinsi Sulawesi Barat, data penderita penyakit DBD ini merupakan data bulanan yang diamati dari Januari 2014-Juli 2016 atau terdiri dari dari 31 pengamatan bulanan.

Proses pembentukan model STAR diawali dengan tahap identifikasi yaitu dengan melihat apakah data telah stasioner atau belum. Kemudian tahap selanjutnya, mengestimasi parameter dengan menggunakan metode kuadrat terkecil (MKT). Setelah itu dilanjutkan dengan melakukan pembobotan untuk mendapatkan model dan terakhir melakukan peramalan dengan menggunakan model yang telah didapat.

\section{HASIL DAN PEMBAHASAN}

\section{Analisis Statistika Deskriptif}

Data yang digunakan adalah data dari Dinas kesehatan Provinsi Sulawesi Barat dari Januari 2014-Juli 2016. Dapat dilihat pada Tabel 1, hasil deskripsi data jumlah penderita penyakit DBD di Provinsi Sulawesi Barat pada setiap peubah.

TABEL 1. Deskripsi Data Jumlah Penderita Penyakit DBD.

\begin{tabular}{lcccc}
\hline \multicolumn{1}{c}{ Peubah } & Rata-rata & Simpangan baku & Maksimum & Minimum \\
\hline Mamuju $\left(\mathrm{Z}_{1}\right)$ & 9,322580645 & 8,537708892 & 42 & 0 \\
Majene $\left(\mathrm{Z}_{2}\right)$ & 2,64516129 & 4,505910097 & 21 & 0 \\
Polmas $\left(\mathrm{Z}_{3}\right)$ & 10,38709677 & 13,42305832 & 64 & 0 \\
Mamuju Tengah $\left(\mathrm{Z}_{4}\right)$ & 6,741935484 & 6,049615646 & 21 & 0 \\
Mamuju Utara $\left(\mathrm{Z}_{5}\right)$ & 14 & 17,55182801 & 75 & 0 \\
\hline
\end{tabular}

Tabel 1 menunjukkan rata-rata penderita tertinggi terjadi di Kabupaten Mamuju Utara $\left(Z_{5}\right)$ dengan jumlah penderita 14 orang sedangkan, rata-rata penderita terendah terjadi di Kabupaten Majene dengan jumlah penderita 2,6.

Disamping itu, perlu diperhatikan apakah ketergantungan antara lokasi dan waktu pada setiap peubah dalam penelitian ini saling berhubungan atau tidak. Hal ini ditunjukkan dengan nilai korelasi yang dinyatakan pada Tabel 2. 
TABEL 2. Korelasi antar setiap peubah

\begin{tabular}{cccccc}
\hline Series & $\mathbf{Z}_{\mathbf{1}}$ & $\mathbf{Z}_{\mathbf{2}}$ & $\mathbf{Z}_{\mathbf{3}}$ & $\mathbf{Z}_{\mathbf{4}}$ & $\mathbf{Z}_{\mathbf{5}}$ \\
\hline $\mathrm{Z}_{1}$ & 1 & 0,83315542 & 0,598339203 & 0,519253222 & 0,286949028 \\
$\mathrm{Z}_{2}$ & & 1 & 0,63503038 & 0,52357131 & 0,1959868 \\
$\mathrm{Z}_{3}$ & & & 1 & 0,522179282 & 0,349180569 \\
$\mathrm{Z}_{4}$ & & & & 1 & 0,237328778 \\
$\mathrm{Z}_{5}$ & & & & & 1 \\
\hline
\end{tabular}

Tabel 2 menunjukkan bahwa setiap lokasi memiliki korelasi yang bernilai positif. Sehingga, dapat disimpulkan bahwa setiap peubah yang ada memiliki pengaruh terhadap peubah lainnya. Korelasi yang memiliki nilai tertinggi yaitu korelasi antara peubah $Z_{1}$ dan $Z_{2}$. Sedangkan, korelasi terendah yaitu korelasi anatar peubah $\mathrm{Z}_{2}$ dan $\mathrm{Z}_{5}$.

Gambar 1 menunjukkan data secara statistikselama periode Januari 2014-Juli 2016.

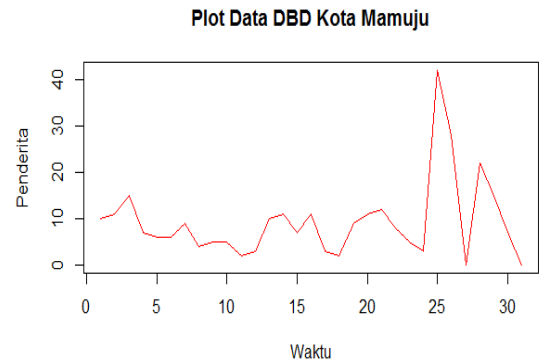

Plot Data DBD Kab. Polmas

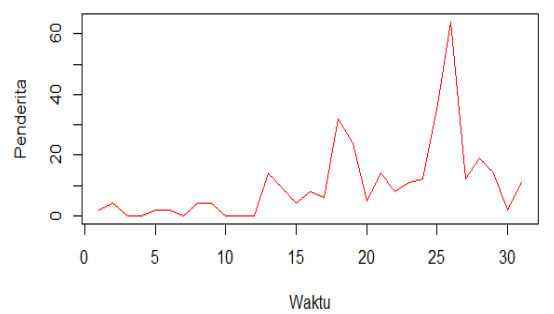

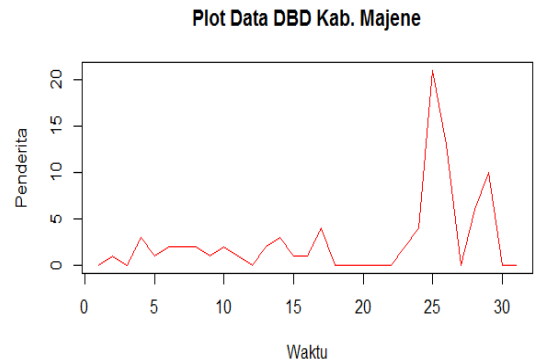

Plot Data DBD Kab. Mamuju Tengah

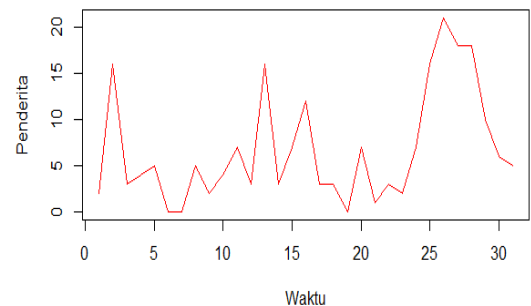

Plot Data DBD Kab. Mamuju Utara

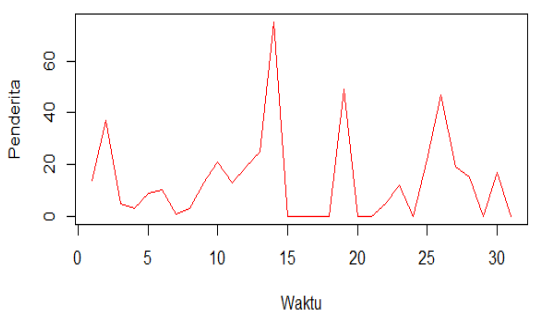

GAMBAR 1. Plot Data Deret Waktu lima lokasi di Provinsi Sulawesi Barat

Secara visual Gambar 1 pada setiap lokasi belum stasioner. Hal ini dapat dilihat grafik runtun waktu mengalami fluktuasi yang tidak berada pada sekitar nilai rata-rata konstan sehingga data perlu distasionerkan.

Salah satu uji kestasioneran data secara formal adalah dengan menggunakan unit root testatau biasa dikenal dengan Augment Dickey-Fuller testdengan memperhatikan nilai p-value. Data dikatakan stasioner apabila nilai $p$-value $<0,05$. Sebaliknya, data tidak stasioner apabila nilai $p$ value $\geq 0,05$. Berikut hasil uji unit root test untuk setiap lokasi pada Tabel 3 . 
TABEL 3. Uji ADF untuk Kestasioneran Data

\begin{tabular}{lccc}
\hline \multicolumn{1}{c}{ Peubah } & Dickey-Fuller & P-Value & Alternative Hypothesis \\
\hline Mamuju $\left(\mathrm{Z}_{1}\right)$ & -2.5073 & 0,3774 & Tidak Stasioner \\
Majene $\left(\mathrm{Z}_{2}\right)$ & -2.5603 & 0.3571 & Tidak Stasioner \\
Polmas $\left(\mathrm{Z}_{3}\right)$ & -3.7099 & 0.04045 & Stasioner \\
Mamuju Tengah $\left(\mathrm{Z}_{4}\right)$ & -3.3721 & 0.07954 & Tidak Stasioner \\
Mamuju Utara $\left(\mathrm{Z}_{5}\right)$ & -3.0163 & 0.1815 & Tidak Stasioner \\
\hline
\end{tabular}

Dari Tabel 3, diperoleh hasil identifikasi kestasioneran terhadap 5 lokasi yang ada di Provinsi Sulawesi Barat. Berdasarkan uji unit root testterdapat 4 lokasi yang tidak stasioner antara lain Kota Mamuju, Kab. Majene, Kab. Mamuju Tengah, dan Kab. Mamuju Utara. Dari 4 lokasi ini, masing-masing nilai $p$-value $>0.05$. Berbeda dengan hasil uji root unit test, Kab. Polmas memiliki nilai $p$-value $<0.05$. Hal ini memenuhi sifat kestasioneran data. Hal ini berbeda dengan hasil visual yang terlihat pada Gambar 1 untuk Kab. Polmas.

Untuk membentuk suatu model yang relevan, sifat kestasioneran data sangatlah penting. Apabila terdapat data yang tidak stasioner maka perlu distasionerkan baik dalam rata-rata maupun dalam varian. Untuk menstasionerkan data jumlah penderita penyakit DBD di Provinsi Sulawesi Barat pada 4 lokasi yang tidak stasioner maka dilakukan differencing sedangkan data yang tidak stasioner dalam varian maka dilakukan transformasi. Tabel 4 menunjukkan hasil uji $\mathrm{ADF}$ untuk data penderita penyakit DBD pada 4 lokasi yang tidak stasioner.

TABEL 4. Uji ADF untuk Kestasioneran Data Hasil Diffrencing

\begin{tabular}{lccc}
\hline \multicolumn{1}{c}{ Peubah } & Dickey-Fuller & P-Value & Alternative Hypothesis \\
\hline Mamuju $\left(\mathrm{Z}_{1}\right)$ & -5.9647 & 0,01 & Stasioner \\
Majene $\left(\mathrm{Z}_{2}\right)$ & -3.7385 & 0.03907 & Stasioner \\
Mamuju Tengah $\left(\mathrm{Z}_{4}\right)$ & -4.484 & 0.01 & Stasioner \\
Mamuju Utara $\left(\mathrm{Z}_{5}\right)$ & -4.431 & 0.01 & Stasioner \\
\hline
\end{tabular}

Tabel 4 menunjukkan bahwa semua data telah stasioner baik dalam rata-rata maupun stasioner dalam varian. Hal ini dapat dilihat dari nilai $p$-value 0.05 untuk setiap lokasi.Gambar 2 menunjukkan secara visual pada setiap lokasi telah stasioner. Hal ini dapat dilihat grafik runtun waktu mengalami fluktuasi yang berada pada sekitar nilai rata-rata konstan.
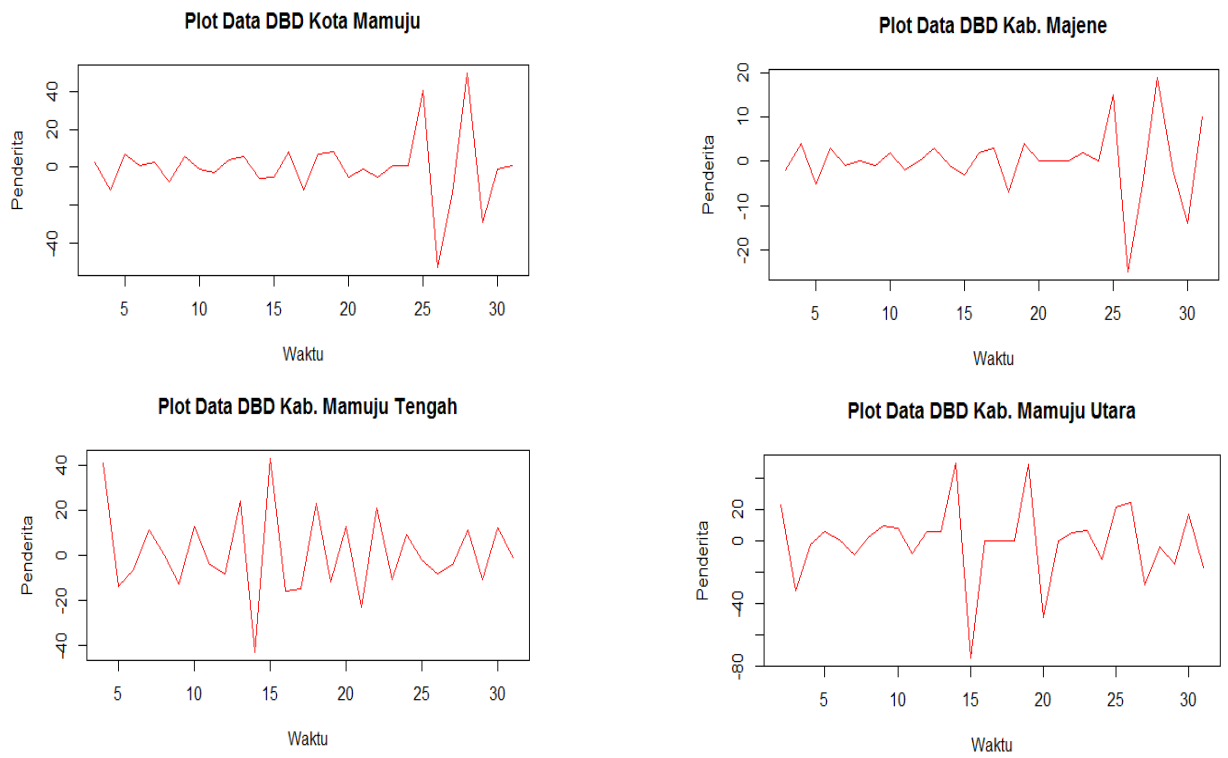

GAMBAR 2. Plot Data Deret Waktu kelima Lokasi Hasil Differencing 
Sesuai dengan teori bobot lokasi seragam, lokasi berdekatan diberikan nilai 1 sebaliknya lokasi yang tidak berdekatan diberikan nilai 0 . Hal ini dianggap bahwa untuk lokasi yang berdekatan memiliki pengaruh yang nyata.

TABEL 5. Bobot Lokasi Seragam

\begin{tabular}{cccccc}
\hline Relasi & $\mathbf{Z}_{\mathbf{1}}$ & $\mathbf{Z}_{\mathbf{2}}$ & $\mathbf{Z}_{\mathbf{3}}$ & $\mathbf{Z}_{\mathbf{4}}$ & $\mathbf{Z}_{\mathbf{5}}$ \\
\hline $\mathrm{Z}_{1}$ & 0 & 1 & 1 & 1 & 0 \\
$\mathrm{Z}_{2}$ & 1 & 0 & 1 & 0 & 0 \\
$\mathrm{Z}_{3}$ & 1 & 1 & 0 & 0 & 0 \\
$\mathrm{Z}_{4}$ & 1 & 0 & 0 & 0 & 1 \\
$\mathrm{Z}_{5}$ & 0 & 0 & 0 & 1 & 0 \\
\hline
\end{tabular}

Tabel 5menunjukkan relasi antara setiap lokasi berdasarkan teori bobot lokasi seragam. Kemudian, dihitung nilai pembobot $w_{i j}$ dimana $i \neq j$ untuk relasi antar lokasi. Dengan memperhatikan persamaan (5).

$$
w_{i j}=\frac{1}{n_{i}}(5)
$$

Dengan $n_{1}$ adalah jumlah lokasi yang berdekatan dengan lokasi ke- $i$ sehingga

$n_{1} \quad=$ Jumlah lokasi yang berdekatan dengan lokasi ke-1 $\left(\mathrm{Z}_{1}\right)$

$n_{2} \quad=$ Jumlah lokasi yang berdekatan dengan lokasi ke-2 $\left(\mathrm{Z}_{2}\right)$

$n_{3} \quad=$ Jumlah lokasi yang berdekatan dengan lokasi ke-3 $\left(\mathrm{Z}_{3}\right)$

$n_{4} \quad=$ Jumlah lokasi yang berdekatan dengan lokasi ke-4 $\left(\mathrm{Z}_{4}\right)$

$n_{5} \quad=$ Jumlah lokasi yang berdekatan dengan lokasi ke-5 $\left(\mathrm{Z}_{5}\right)$

Matriks pembobot dapat dilihat pada persamaan (6)

$$
W=\left[\begin{array}{ccccc}
0 & W_{1,2} & W_{1,2} & W_{1,2} & W_{1,2} \\
W_{1,2} & 0 & W_{1,2} & W_{1,2} & W_{1,2} \\
W_{1,2} & W_{1,2} & 0 & W_{1,2} & W_{1,2} \\
W_{1,2} & W_{1,2} & W_{1,2} & 0 & W_{1,2} \\
W_{1,2} & W_{1,2} & W_{1,2} & W_{1,2} & 0
\end{array}\right] W=\left[\begin{array}{ccccc}
0 & \frac{1}{n_{1}} & \frac{1}{n_{1}} & \frac{1}{n_{1}} & \frac{1}{n_{1}} \\
\frac{1}{n_{2}} & 0 & \frac{1}{n_{2}} & \frac{1}{n_{2}} & \frac{1}{n_{2}} \\
\frac{1}{n_{3}} & \frac{1}{n_{3}} & 0 & \frac{1}{n_{3}} & \frac{1}{n_{3}} \\
\frac{1}{n_{4}} & \frac{1}{n_{4}} & \frac{1}{n_{4}} & 0 & \frac{1}{n_{4}} \\
\frac{1}{n_{5}} & \frac{1}{n_{5}} & \frac{1}{n_{5}} & \frac{1}{n_{5}} & 0
\end{array}\right]
$$

Selanjutnya nilai pada matriks pembobot dimasukkan dengan memperhatikan relasi antara setiap lokasi seperti pada Tabel 5.

$$
W=\left[\begin{array}{ccccc}
0 & \frac{1}{Z_{1,2}+Z_{1,3}+Z_{1,4}} & \frac{1}{Z_{1,2}+Z_{1,3}+Z_{1,4}} & \frac{1}{Z_{1,2}+Z_{1,3}+Z_{1,4}} & 0 \\
\frac{1}{Z_{1,1}+Z_{1,3}} & 0 & \frac{1}{Z_{1,1}+Z_{1,3}} & 0 & 0 \\
\frac{1}{Z_{1,1}+Z_{1,2}} & \frac{1}{Z_{1,1}+Z_{1,2}} & 0 & 0 & 0 \\
\frac{1}{Z_{1,1}+Z_{1,5}} & 0 & 0 & 0 & \frac{1}{Z_{1,1}+Z_{1,5}} \\
0 & 0 & 0 & \frac{1}{Z_{1,2}} & 0
\end{array}\right]
$$




$$
\begin{gathered}
W=\left[\begin{array}{cccccc}
0 & \frac{1}{1+1+1} & \frac{1}{1+1+1} & \frac{1}{1+1+1} & 0 \\
\frac{1}{1+1} & 0 & \frac{1}{1+1} & 0 & 0 \\
\frac{1}{1+1} & \frac{1}{1+1} & 0 & 0 & 0 \\
\frac{1}{1+1} & 0 & 0 & 0 & \frac{1}{1+1} \\
0 & 0 & & 0 & 1 & 0
\end{array}\right] \\
W=\left[\begin{array}{cccccc}
0 & \frac{1}{3} & \frac{1}{3} & \frac{1}{3} & 0 \\
\frac{1}{2} & 0 & \frac{1}{2} & 0 & 0 \\
\frac{1}{2} & \frac{1}{2} & 0 & 0 & 0 \\
\frac{1}{2} & 0 & 0 & 0 & \frac{1}{2} \\
0 & 0 & 0 & 1 & 0
\end{array}\right] \\
W=\left[\begin{array}{ccccc}
0 & 0.33 & 0.33 & 0.33 & 0 \\
0.5 & 0 & 0.5 & 0 & 0 \\
0.5 & 0.5 & 0 & 0 & 0 \\
0.5 & 0 & 0 & 0 & 0.5 \\
0 & 0 & 0 & 1 & 0
\end{array}\right]
\end{gathered}
$$

Metode Kuadrat Terkecil (MKT) adalah salah satu cara dalam penaksiran parameter model STAR dengan meminimumkan jumlah kuadrat simpangannya. Jika jumlah pengamatan $Z_{5}(31), t=0,1,2,3, \ldots, 31$, untuk lokasi $i=1,2, \ldots, 5$ dengan,

$$
Z_{5}(31)=\sum_{j=1}^{5} w_{i j} Z_{j}(31)
$$

Maka model untuk lokasi ke- $i, i=1,2,3, \ldots, 5$ dapat ditulis dalam bentuk linear: $Y_{i}=X_{i} \beta_{i}+u_{i}$, dimana $i=1,2,3, \ldots, 5$

Estimasi dengan metode kuadrat terkecil adalah sebagai berikut:

$$
\beta_{i}=\left[X^{T} X\right]^{-1} X^{T} Y
$$

TABEL 6. Parameter Penduga dengan Bobot Lokasi Seragam

\begin{tabular}{ccccc}
\hline Parameter & Nilai Pendugaan & $\boldsymbol{t}$-value & $\boldsymbol{p}$-value \\
\hline$\Phi_{10}$ & -0.06 & -0.18 & 0.85 \\
& $\phi_{20}$ & 1.00 & 1.38 & 0.16 \\
& $\phi_{30}$ & 0.67 & 3.47 & $0.0006^{*}$ \\
$\phi_{40}$ & 0.50 & 1.54 & 0.12 \\
$\phi_{50}$ & 0.07 & 0.62 & 0.53 \\
$\phi_{11}$ & 1.07 & 2.47 & $0.01^{*}$ \\
$\phi_{12}$ & $6 \times 10^{-16}$ & $5 \times 10^{-16}$ & 1.00 \\
$\phi_{13}$ & -0.05 & -0.14 & 0.88 \\
$\phi_{14}$ & 0.18 & 1.00 & 0.31 \\
$\phi_{15}$ & 1.43 & 5.18 & $7 \times 10^{-7 *}$ \\
\hline
\end{tabular}

*adalah parameter yang signifikan

Parameter-parameter yang nyata adalah parameter yang memiliki nilai $p$-value $<0.05$ yaitu parameter $\Phi_{30}, \Phi_{11 \text {, dan }} \Phi_{15}$ dengan nilai p-value masing masing adalah $0.0006,0,01$, dan 7 x $10^{-}$ 
7. Parameter-parameter ini diduga memiliki pengaruh nyata terhadap waktu-waktu sebelumnya atau lokasi yang lainnya.

Diperoleh model STAR ${ }_{5}\left(1_{1}\right)$ untuk lokasi seragam adalah sebagai berikut:

$$
\begin{gathered}
Z_{1}(t)=-0.06 Z_{1}(t-1)+0.3531\left(Z_{2}(t-1)+Z_{3}(t-1)+Z_{4}(t-1)\right) \\
Z_{2}(t)=1.00 Z_{2}(t-1)+3 \times 10^{-16}\left(Z_{1}(t-1)+Z_{3}(t-1)\right) \\
Z_{3}(t)=0.67 Z_{3}(t-1)+0.025\left(Z_{1}(t-1)+Z_{2}(t-1)\right) \\
Z_{4}(t)=0.50 Z_{4}(t-1)+0.09\left(Z_{1}(t-1)+Z_{5}(t-1)\right) \\
Z_{5}(t)=0.07 Z_{5}(t-1)+1.43 Z_{4}(t-1)
\end{gathered}
$$

Hasil ramalan model $\operatorname{STAR}_{5}\left(1_{1}\right)$ dengan menggunakan bobot lokasi seragam untuk kelima lokasi yaitu Mamuju $\left(\mathrm{Z}_{1}\right)$, Majene $\left(\mathrm{Z}_{2}\right)$, Polmas $\left(\mathrm{Z}_{3}\right)$, Mamuju Tengah $\left(\mathrm{Z}_{4}\right)$ dan Mamuju Utara (Z5) ditunjukkan padaTabel 7.

TABEL 7. Hasil Ramalan Model $\operatorname{STAR}_{5}\left(1_{1}\right)$

\begin{tabular}{lccccc}
\hline \multicolumn{1}{c}{ Bulan - Tahun } & $\begin{array}{c}\text { Mamuju } \\
\left(\mathbf{Z}_{1}\right)\end{array}$ & $\begin{array}{c}\text { Majene } \\
\left(\mathbf{Z}_{2}\right)\end{array}$ & $\begin{array}{c}\text { Polmas } \\
\left(\mathbf{Z}_{3}\right)\end{array}$ & $\begin{array}{c}\text { Mamuju } \\
\text { Tengah }\left(\mathbf{Z}_{4}\right)\end{array}$ & $\begin{array}{c}\text { Mamuju } \\
\text { Utara }\left(\mathbf{Z}_{5}\right)\end{array}$ \\
\hline Agustus - 2016 & 6 & 0 & 7 & 3 & 7 \\
September - 2016 & 3 & 0 & 5 & 3 & 5 \\
\hline
\end{tabular}

Tabel 7 menunjukkan bahwa hasil ramalan pada bulanAgustus sampai September 2016 mengalami penurunan yang signifikan terhadap kelima lokasi di Provinsi Sulawesi Barat.

\section{KESIMPULAN}

Berdasarkan hasil peneltian ini, dapat ditarik kesimpulan bahwa model yang didapat untuk meramalkan data jumlah penderita penyakit DBD di Provinsi Sulawesi Barat dengan melihat parameter-parameter yang diduga memiliki pengaruh yang nyata. Sehingga, hanya ada 3 model saja yang layak untuk digunakan yaitu $Z_{1}, Z_{3}$, dan $Z_{5}$. Model $Z_{2}$ dan $Z_{4}$ dapat digunakan tetapi dengan nilai p-value $>0.05$ akan membuat hasil dari ramalan kurang begitu tepat.

Penelitianselanjutnya terkait dengan model Space Time (ruang waktu) dapat menggunakan lebih dari 1 pembobotan dan penaksiran parameternya dapat menggunkan metode selain metode kuadrat terkecil (MKT) seperti stepwise, SUR, dan lainnya.

\section{DAFTAR PUSTAKA}

Daraputri S. (2015). Penerepan Model Generalized Space Time Pada Harga Gula Pasir di Pulau Jawa. Institut Pertanian Bogor, Bogor.

Ilham. (2017). Pemodelan Generalized Space Time Autoregressive (GSTAR) Penderita Penyakit ISPA di Kabupaten Jeneponto. Universitas Negeri Makassar, Makassar.

Kementerian Kesehatan RI. (2010). Demam Berdarah Dengue di Indonesia Tahun 1968-2009. Buletin Jendela Epidemiologi 2 pp. 1-14. Kementerian Kesehatan RI. Jakarta.

Pfeifer PE\& Deutsch SJ. (1980). A three-stage iterative procedure for space-time modeling. Technometrics. 22:35-47

Purnomo F. S. (2015). Penggunaan Metode ARIMA (Autoregressive integrated Moving Average) untuk Prakiraan Beban Konsumsi Listrik Jangka Pendek (Short Term Forecasting). Universitas Negeri Semarang. 
Rahman, S.P.H. (2013). Metode Analisis Harga Pangan Pusat Analisis Sosial Ekonomi dan Kebijakan Pertanian Bogor.

Retnaningrum, (2015). Penerapan Model STAR (Space Time Autoregressive) dan ARIMA (Autoregressive Integrated Moving Average) untuk Peramalan Data Curah Hujan di Kab Jember. Universitas Jember, Jember.

Suhartini. (2007). Peramalan dengan Model ARCH. Universitas Sanata Dharma

Suhartono \& Wutsqa D.U. (2007). Perbandingan Model VAR dan STAR pada Peramalan Produksi Teh di Jawa Barat. Institut Teknologi Sepuluh November, Surabaya.

Suryamah E., Ruchjana BN., Joebaedi. (2013). Kajian Matriks Bobot Lokasi Model Space Time Autoregresi (STAR). Jurnal Matematika Integratif 9(2), (pp. 119-130). Jurusan Matematika, Fakultas MIPA, Universitas Padjadjaran. 